\title{
ETHNOMYCOLOGICAL KNOWLEDGE OF SOME WILD MUSHROOMS OF NORTHERN DISTRICTS OF JAMMU AND KASHMIR, INDIA
}

\author{
ABDUL RASHID MALIK*, ABDUL HAMID WANI, MOHD YAQUB BHAT, SHAZIA PARVEEN
}

Department of Botany, Section of Mycology and Plant Pathology, University of Kashmir, Hazratbal, Srinagar - 190 006, Jammu and Kashmir, India. Email: armalik2000@gmail.com

Received: 10 February 2017, Revised and Accepted: 13 June 2017

\begin{abstract}
Objective: Mushrooms are known for their nutritional and medicinal importance from ancient times throughout the world. The use of mushrooms as valuable tonic, food, and ethnomedicines has also been reported from India. However, information on the ethnomedicinal use of mushrooms is not available from the surveyed area of Kashmir valley. Therefore, the objective of this work is to study the ethnomedicinal use of wild mushrooms from the Northern districts of Jammu and Kashmir.
\end{abstract}

Materials and Methods: Different remote areas of Northern districts, Baramulla and Kupwara of Kashmir Valley were surveyed to document the indigenous use of various mushrooms growing in the area by local tribal people and local herbalists. Mushroom hunters, local Hakims, herbalists and aged people from tribal communities and nomads were consulted, interviewed and taken as guides to collect various mushroom species.

Results: The mushroom samples collected from the study area were used as a source of food and medicines for different ailments. The specimens collected were photographed by Sony cyber shot 12.1 megapixel camera in their natural habitats and were identified on the basis of macro and microscopic characters, expert mushroom taxonomists, field guides and standard related literature. The study revealed that 33 mushroom species belonging to Ascomycetes and Basidiomycetes were used for their nutritional and medicinal values. These mushrooms were used by the local hakims against various ailments ranging from respiratory, blood and heart ailments, arthritis, nervous and urogenital diseases either alone or in combination with some herbs.

Conclusions: It was concluded from this study that all the mushrooms used by the local tribal people and local herbalists for different ailments can be further evaluated for medicinal value and for bioactive constituents.

Keywords: Wild mushrooms, Ethnomycological studies, Food and medicinal values, Mushroom hunters, Kashmir valley.

(c) 2017 The Authors. Published by Innovare Academic Sciences Pvt Ltd. This is an open access article under the CC BY license (http://creativecommons. org/licenses/by/4. 0/) DOI: http://dx.doi.org/10.22159/ajpcr.2017.v10i9.17641

\section{INTRODUCTION}

The collection and use of wild mushrooms by human beings is an age old practice. The consumption of wild fungi by Chinese has been reliably noted several 100 years before the Christ's birth, and now they are being commercially exploited world over with an average value of about 2 billon US dollars in 2004 [1]. Of this nonconventional forest wealth, about 3000 species belonging to 31 genera are edible, among which 100 species are now economically cultivated and 60 are grown commercially, and out of which 10 have been raised to industrial scale. Mushrooms have been used as a valuable source of food and medicine all over the world. The active constituents found in mushroom are: Polysaccharides, dietary fibers, selenium oligosaccharides, triterpenoids, peptides, proteins, alcohol, phenols, amino acids, and mineral elements. They show anticancerous, antidiabetic, antiviral activity and also ameliorate toxic effects of chemo, and radiotherapy [2-6]. In addition to these, mushrooms contain a wide variety of bioactive molecules such as terpenoids, steroids, phenols, nucleotides and their derivatives, glycoproteins, and polysaccharides. Mushroom proteins contain all the essential amino acids and are especially rich in lysine and leucine. The low total fat content and high proportion of polyunsaturated fatty acids relative to the total fatty acids of mushrooms are considered significant contributors to the health value of mushrooms $[7,8]$. Mushrooms have also been used as a source of folklore medicines [911]. The Himalayan mountain range of Indian subcontinent contributes a major portion of this forest wealth, where their ethnomycological use has been reported by many mycologists $[12,13]$. However, there is a limited knowledge of ethnomycological use of macrofungi in Jammu and Kashmir state of Indian subcontinent, and Northern Kashmir Himalaya stands virgin and hitherto unexplored with none of the reports in the literature.
Therefore, rationale of our study was to carry out ethnomycological survey in district Kupwara and Baramulla of Kashmir Valley, to document the diversity and use of different mushroom species as ethnomedicines and to gather the knowledge related to the occurrence, and distribution of the wild mushrooms in the study area.

\section{MATERIALS AND METHODS}

For this study field trips were conducted at regular intervals between March 2013 and March 2015 in remote areas of Kupwara and Baramulla districts of North Kashmir Himalayas. The surveyed area include Qaziabad, Mawar, Ramhal and Rajwar in Bungus Valley, Chowkibal, Gushi and Kupwara main, Chandigam, Devar and Kalaroos in Lolab Valley, and forest areas of Rafiabad, Baramulla and Wagoora Tehsils of Kashmir Valley. Samples of mushrooms were collected in separate paper bags [14]. During the field survey help of mushroom hunters, local herbal healers (Hakims) and local tribal people were sought to reveal the necessary information regarding the vernacular names, occurrence, edibility, and ethnomedicinal use of mushrooms (Fig. 1a and b). Ethnomycological knowledge was procured from the local informants, old and experienced persons using questionnaire and recording interviews. Field notes were prepared with respect to soil type, forest type, mycorrhizal association, date of collection, and the specimen were photographed using Sony cyber shot 12.1 megapixel (DSC-W310) camera in their natural habitats and some of the morphological characters, viz., shape, color, size, color change on bruising, and taste and odor were noted (Fig. 2). The samples were taken to the laboratory for further examination. Spore shape, color, and size were studied after taking the spore prints on a paper $[15,16]$. 
The samples were identified on the basis of macro and microscopic observations, mushroom herbaria, by consulting field mushroom guides and other standard related available literature [17-19]. Expert mushroom taxonomists were also consulted for final identification of mushrooms. The specimens were preserved after shade drying [20,21]. The fungal specimens were also preserved in formaldehyde acetic acid, and formalin for herbarium purposes and preserved in fungal collection section of KASH herbarium of Plant Taxonomy, Section of Mycology and Plant Pathology, Division of Botany, the University of Kashmir, India.

\section{RESULTS}

This study documented the ethnomycological use of 33 species of medicinal and edible mushrooms belonging to 23 genera and 17

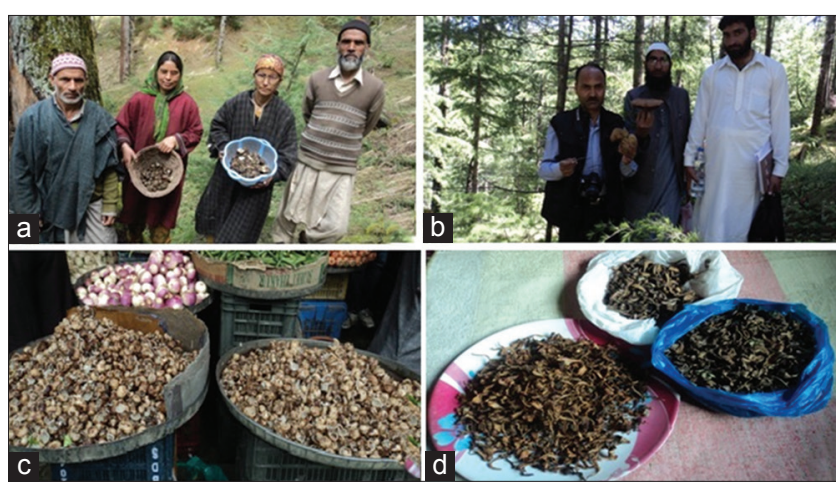

Fig. 1: (a) Mushroom hunters during collection, (b) local guides with the author, (c) mushrooms on grocery shop, (d) dried mushrooms for use in winter families. The mushroom species collected from the surveyed areas, in a diverse range of habitats such as coniferous forests, deciduous forests, and alpine and subalpine pastures, with their scientific name, local name, family, habit and habitat, site of collection, seasonal occurrence, ethnomedicinal uses, and other medicinal uses are listed in Table 1. It was observed from the study that besides being consumed as food, local people, hakims and tribal people inhabiting the surveyed areas use different modes of preparation of mushrooms for the treatment of a number of body ailments such as dermatitis, respiratory diseases, kidney disorders, cardiac problems, jaundice, diabetes, gastrointestinal problems, and tumors. It was revealed from this study that mushrooms, Bovista plumbea, Coprinus comatus, Disciotis venosa, Lentinus tigrinus, Helvella crispa, and Geopora sumneriana were used as ethnomedicines against chest ailments and anticold in the surveyed areas by local herbalists. Similarly, Ganoderma species, Flammulina velutipes, Fomes fomentarius, Helvella acetabulum, and Lycoperdon perlatum are used as immunomodulators and ethnomedicines for the treatment of skin ailments. Ethnomedicinal use of Boletus edulis and Cantharellus cibarius for bone ailments and Lactarius deliciosus for curing gastric irritations was also recorded in the area under study. Many species such as Morchella, L. deliciosus, G. sumneriana, Sparassis sp., and Rhizopogon species are used as functional foods whereas Agaricus sp., Neolentinus lepideus, Phallus impudicus, and Pleurotus ostreatus are widely used as food either fresh or in the dried form (Fig. 1c and d).

Some of the mushroom species such as Geopora, Helvella, Pleurotus, Coprinus, and Morchella are sold in the local markets and is a good source of income for the inhabitants of the area. This study also revealed that many mushrooms were used as a source of food in the study aea, however, mode of consumption and edibility status of these mushrooms varied from area to area. Species such as Agaricus campestris, A. bisporus, B. edulis, L. tigrinus, Lactarius deliciosus,
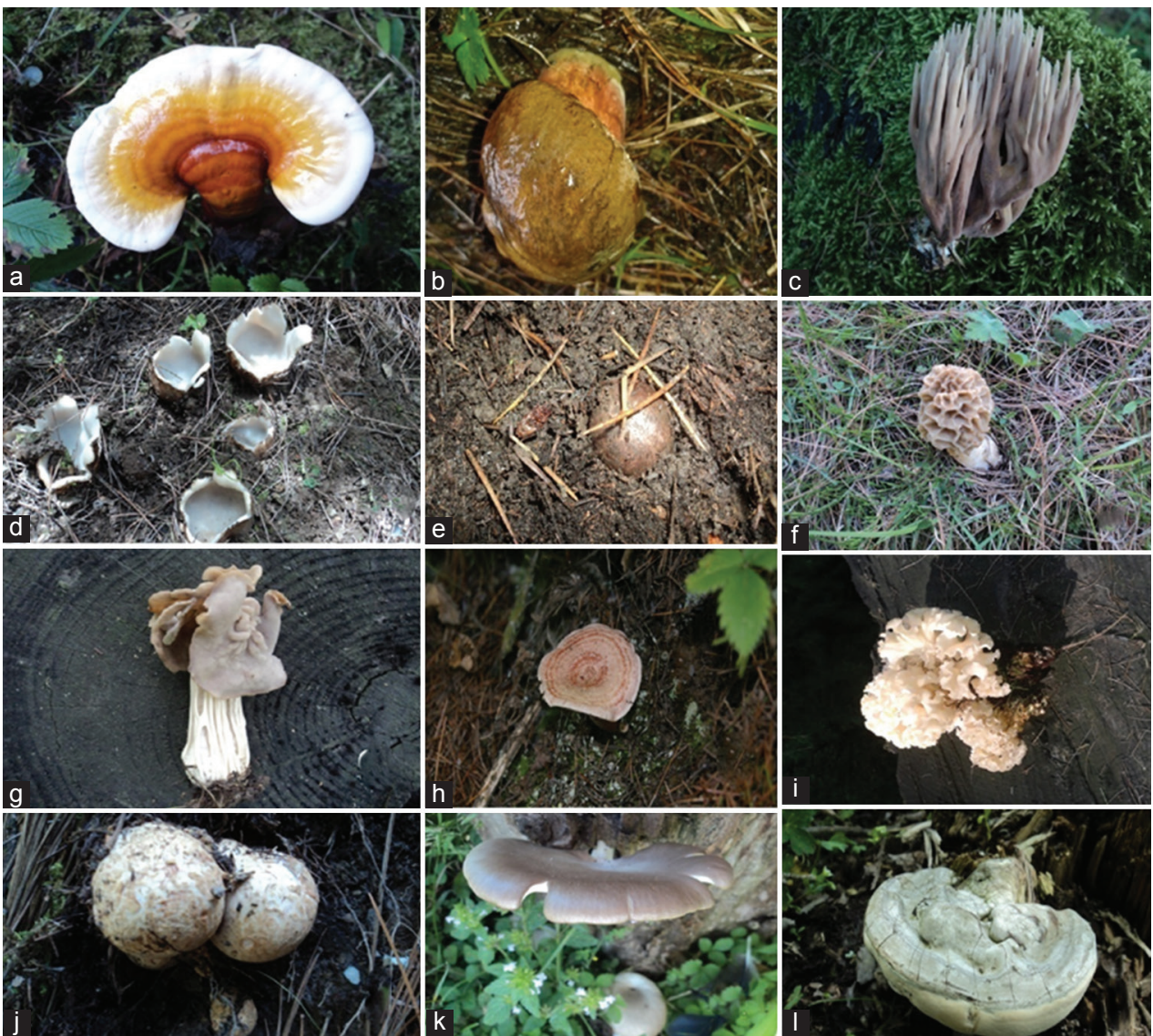

Fig. 2: Wild mushrooms of the surveyed area: (a) Ganoderma lucidum, (b) Boletus edulis, (c) Rameria stricta, (d) Geopora sumneriana, (e) Rhizopogon villosulus, (f) Morchella esculanta, (g) Helvella crispa, (h) Lactarius deliciosus, (i) Sparasis crispa, (j) Rhizopogon roseolus, (k) Pleurotus ostreatus, and l) Fomis fomentarius 
Table 1: Ethnomedicinal use of mushrooms of two Northern Districts of Kashmir Himalaya

\begin{tabular}{|c|c|c|c|c|c|}
\hline S. No. & Scientific name & $\begin{array}{l}\text { Local } \\
\text { name }\end{array}$ & $\begin{array}{l}\text { Ethnomedicinal uses and mode of } \\
\text { consumption }\end{array}$ & $\begin{array}{l}\text { Reported medicinal } \\
\text { uses }\end{array}$ & Month of collection \\
\hline 1 & $\begin{array}{l}\text { Agaricus augustus } \\
\text { Fries }\end{array}$ & Haend & $\begin{array}{l}\text { Widely used as food and general tonic. } \\
\text { Prescribed as a supplementary diet to } \\
\text { patients suffering from asthma, stroke, } \\
\text { heart ailments, and diabetes }\end{array}$ & Antioxidant & Jul-September \\
\hline 2 & $\begin{array}{l}\text { Agaricus bisporus } \\
\text { (Lange) } \\
\text { Imbach }\end{array}$ & Haend & Widely used as food and general tonic & Antioxidant & July-October \\
\hline 3 & $\begin{array}{l}\text { Agaricus campestris } \\
\text { L.: Fr. }\end{array}$ & Haend & $\begin{array}{l}\text { General tonic } \\
\text { Immunomodulators. Prescribed to } \\
\text { diabetic patients }\end{array}$ & $\begin{array}{l}\text { Antihyperglycemic, } \\
\text { insulin releasing }\end{array}$ & July-October \\
\hline 4 & Boletus edulis Bull. & Rate & $\begin{array}{l}\text { Believed to be iron rich, prescribed to } \\
\text { women after deliveries either alone or } \\
\text { with dandelion } \\
\text { As expectorant, antidepressant, treating } \\
\text { lumbago, leg pains, numbness in limbs } \\
\text { and tendon discomfort. However not } \\
\text { recommended for patients with kidney } \\
\text { stones }\end{array}$ & $\begin{array}{l}\text { Antioxidant, extracts } \\
\text { used in treating sarcoma } \\
180 \text { in mice }\end{array}$ & $\begin{array}{l}\text { May-June, } \\
\text { October-November }\end{array}$ \\
\hline 5 & Bovista plumbea Pers. & Badul & $\begin{array}{l}\text { Cooked in milk with some preliminary } \\
\text { treatment given against respiratory } \\
\text { tract infections after boiling in milk and } \\
\text { concentrated to powder form is used } \\
\text { against frost bites }\end{array}$ & $\begin{array}{l}\text { Treatment of tonsillitis, } \\
\text { sore throats, curing } \\
\text { of skin ulcers. To stop } \\
\text { bleeding }\end{array}$ & May-October \\
\hline 6 & $\begin{array}{l}\text { Cantharellus cibarius } \\
\text { Fr. }\end{array}$ & $\begin{array}{l}\text { Pueh } \\
\text { Heand }\end{array}$ & $\begin{array}{l}\text { Believed to cure wounds when used } \\
\text { in powdered form because of its color } \\
\text { resemblance with turmeric. Besides, it } \\
\text { is believed to be a natural tonic. Used } \\
\text { against bone ailments and general } \\
\text { weakness. Dried forms used as vegetable } \\
\text { in the off season }\end{array}$ & $\begin{array}{l}\text { Contains } 8 \text { essential } \\
\text { amino acids and vitamin } \\
\text { A. Frequent consumption } \\
\text { may be effective for } \\
\text { night blindness, } \\
\text { dry skin, infections } \\
\text { of respiratory tract, } \\
\text { inflammation of eye } \\
\text { and sarcoma }\end{array}$ & July-August \\
\hline 8 & $\begin{array}{l}\text { Disciotis } \\
\text { venosa (Pers.) } \\
\text { Arnould }\end{array}$ & $\begin{array}{l}\text { Kana } \\
\text { Guech }\end{array}$ & $\begin{array}{l}\text { Widely used as food. However some } \\
\text { communities use against common cold } \\
\text { as culinary preparations with chili and } \\
\text { eggs }\end{array}$ & No reports & March-April \\
\hline 9 & $\begin{array}{l}\text { Flammulina } \\
\text { velutipes (Curt.) } \\
\text { Singer }\end{array}$ & Heand & Given as a tonic and immunomodulator & $\begin{array}{l}\text { May prevent, as well as } \\
\text { cure, liver disease, and } \\
\text { gastro enteric ulcers }\end{array}$ & November-December \\
\hline 10 & $\begin{array}{l}\text { Fomes } \\
\text { fomentarius (L.) Fr. }\end{array}$ & Heand & $\begin{array}{l}\text { Its ash mixed with oil is used against } \\
\text { skin ailments. Small slices are } \\
\text { prescribed in vegetables for } \\
\text { hypertensive patients }\end{array}$ & $\begin{array}{l}\text { Diuretic, antimicrobial, } \\
\text { wound healing }\end{array}$ & Round the year \\
\hline 11 & $\begin{array}{l}\text { Ganoderma } \\
\text { applanatum (Pers.) } \\
\text { Pat. }\end{array}$ & Heand & $\begin{array}{l}\text { Decoction given to patients with weak } \\
\text { immune systems. Local herbalists use it } \\
\text { along with honey and Kaloongi against } \\
\text { cough and common cold }\end{array}$ & $\begin{array}{l}\text { Has immune-stimulating } \\
\text { properties, fights } \\
\text { cancers, stops pain, } \\
\text { eliminates indigestion, } \\
\text { reduces phlegm, } \\
\text { antibiotic, antiviral }\end{array}$ & May-August \\
\hline 12 & $\begin{array}{l}\text { Ganoderma } \\
\text { lucidum (Leysser) } \\
\text { Karsten }\end{array}$ & Heand & $\begin{array}{l}\text { As tea against multiple ailments, mostly } \\
\text { given to the patients recovering from } \\
\text { prolonged illness }\end{array}$ & $\begin{array}{l}\text { In treating hepatitis, } \\
\text { chronic bronchitis; } \\
\text { coronary heart } \\
\text { disease, allergies, and } \\
\text { altitude sickness. For } \\
\text { aging-related } \\
\text { conditions, } \\
\text { anticancer and as an } \\
\text { immunomodulator }\end{array}$ & May-August \\
\hline
\end{tabular}


Table 1: (Continued)

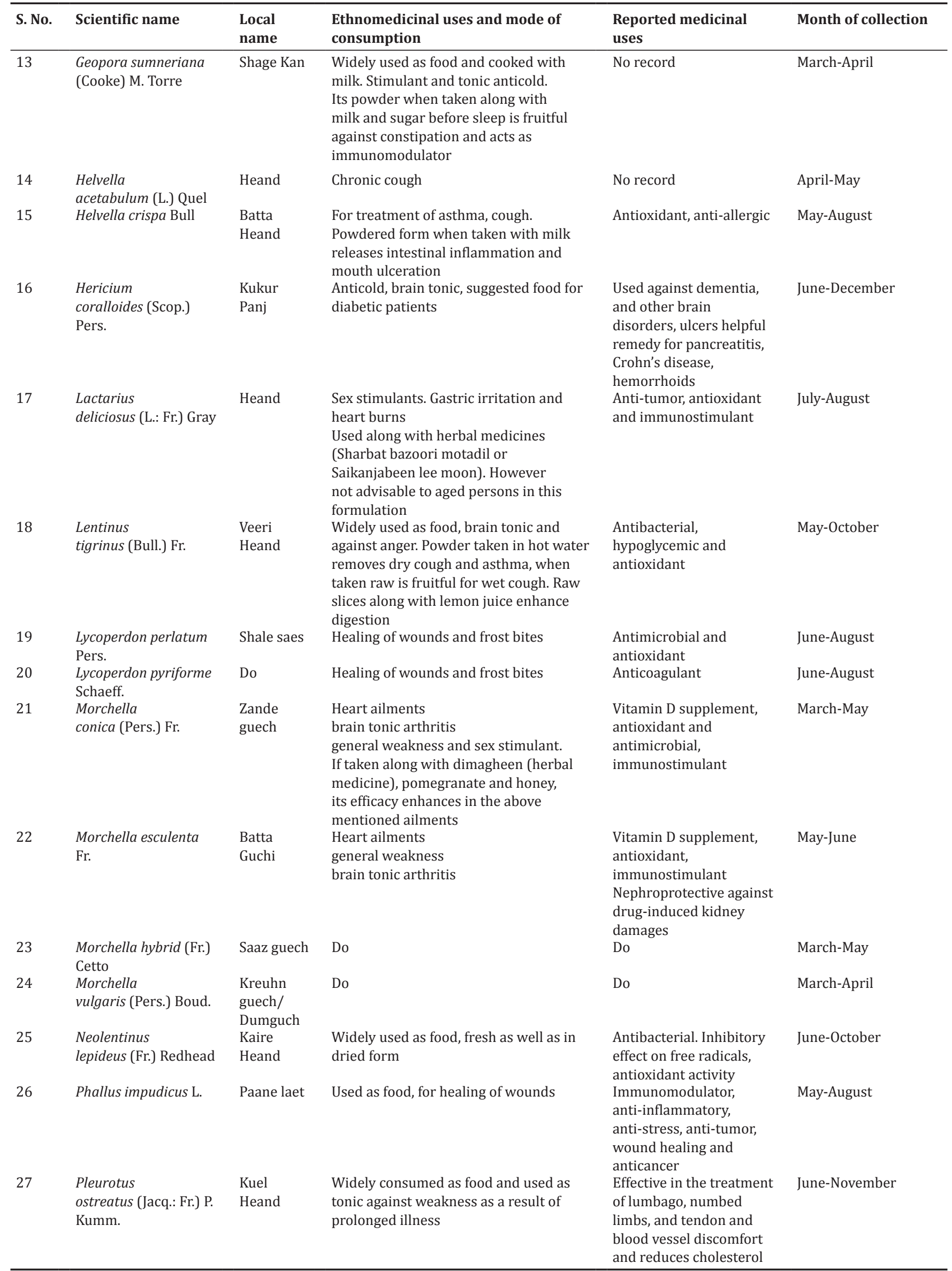


Table 1: (Continued)

\begin{tabular}{|c|c|c|c|c|c|}
\hline S. No. & Scientific name & $\begin{array}{l}\text { Local } \\
\text { name }\end{array}$ & $\begin{array}{l}\text { Ethnomedicinal uses and mode of } \\
\text { consumption }\end{array}$ & $\begin{array}{l}\text { Reported medicinal } \\
\text { uses }\end{array}$ & Month of collection \\
\hline 28 & $\begin{array}{l}\text { Ramaria } \\
\text { stricta (Pers.) Quel. }\end{array}$ & Rai Saad & $\begin{array}{l}\text { Asthma and other respiratory ailments. } \\
\text { After boiling its filtrate is used for } \\
\text { stimulation of nervous system. Its } \\
\text { powder along with herbal medicines } \\
\text { Stumble tayeb and Shahtara is used as } \\
\text { blood purifier and enhancing skin color } \\
\text { Used for eye ailments along with pepper. } \\
\text { In winters its powder along with pepper } \\
\text { and clove reduces lung inflammation }\end{array}$ & No reports & June-October \\
\hline 29 & $\begin{array}{l}\text { Rhizopogon villosulus } \\
\text { Zeller }\end{array}$ & $\begin{array}{l}\text { Deodar } \\
\text { Mungrae }\end{array}$ & $\begin{array}{l}\text { Used raw or as vegetable } \\
\text { Its powder along with herbal extract of } \\
\text { Aaloo Baloo and Sang i sarmahi is used } \\
\text { against kidney stones and urinary tract } \\
\text { infections. When powdered form is used } \\
\text { along with Zoofa an ayurvedic medicine } \\
\text { cures fatty liver and asthma }\end{array}$ & Squirrel diet & March-May \\
\hline 30 & $\begin{array}{l}\text { Rhizopogon roseolus } \\
\text { Corda }\end{array}$ & $\begin{array}{l}\text { Madaan } \\
\text { Mungrae }\end{array}$ & Treatment of urinary tract infections & $\begin{array}{l}\text { Antioxidant, } \\
\text { antimicrobial }\end{array}$ & March-November \\
\hline 31 & $\begin{array}{l}\text { Sparassis crispa } \\
\text { Wulfen }\end{array}$ & $\begin{array}{l}\text { Kawa } \\
\text { khour }\end{array}$ & $\begin{array}{l}\text { General tonic, blood purifier and } \\
\text { anticold. Local hakims use its powder } \\
\text { along with Aaloo Baloo (herbal } \\
\text { medicine) in the ratio of 1:5 against } \\
\text { memory loss, depression, anger and } \\
\text { chest pains } \\
\text { Powdered Mushroom along with } \\
\text { adiantum powder and Kaloongi is used } \\
\text { to cure asthma }\end{array}$ & $\begin{array}{l}\text { Enhances hemoglobin } \\
\text { level and anti-tumor } \\
\text { properties }\end{array}$ & June-October \\
\hline 32 & $\begin{array}{l}\text { Sparassis } \\
\text { spathulata (Schwein.) } \\
\text { Fr. }\end{array}$ & $\begin{array}{l}\text { Raisaad/ } \\
\text { Kawkhour }\end{array}$ & $\begin{array}{l}\text { Mainly used as food and General tonic } \\
\text { and anticold, blood purifier when } \\
\text { cooked along with milk }\end{array}$ & Not reported & June-October \\
\hline 33 & $\begin{array}{l}\text { Trametes } \\
\text { versicolor (L.) Lloyd. }\end{array}$ & Heand & $\begin{array}{l}\text { Effective against skin diseases such as } \\
\text { rashes, itching, dryness, and healing of } \\
\text { wounds when used with butter or oil }\end{array}$ & $\begin{array}{l}\text { Secondary prevention } \\
\text { strategy as immune } \\
\text { therapy against breast } \\
\text { cancer }\end{array}$ & Round the year \\
\hline
\end{tabular}

Table 2: Knowledge of tribal and local people with regard to mushrooms

\begin{tabular}{llll}
\hline \multirow{2}{*}{ District } & Tehsil & \multicolumn{2}{l}{ Knowledge of mushroom utilization } \\
\cline { 3 - 4 } & & Food & Ethnomedicine \\
\hline Kupwara & Handwara & $16.67 \pm 2.89^{*}$ & $1.67 \pm 1.53$ \\
& Kupwara & $16.67 \pm 5.77$ & $1.33 \pm 0.58$ \\
Baramulla & Baramulla & $11.67 \pm 10.40$ & $2.67 \pm 2.52$ \\
& Wagoora & $2.33 \pm 2.52$ & $0.33 \pm 0.58$ \\
& Rafiabad & $20.00 \pm 0.00$ & $1.67 \pm 0.57$ \\
\hline
\end{tabular}

*Mean \pm SD of three sample sites with a sample size of 20 each. SD: Standard deviation

Morchella spp., P. ostreatus, Rhizopogon sp., G. sumneriana, Cantharellus cibarius, Sparassis crispa, S. spathulata, and Hericium corolloides are considered highly delicious, while H. crispa, Ramaria stricta, and Disciotis venosa have good acceptability for consumption. Ramaria species were used as medicine and cooked in the Ramhal area of Kupwara district but not from other areas, likewise, C. cibarius and $B$. plumbea are consumed as food and medicine in some areas of Bungus valley and not in others. Morchella spp., Sparassis sp., Geopora, L. deliciosus, P. ostreatus, Agaricus sp., Hericium coralloides, and B. edulis are almost consumed as food in all the areas and for the treatment of several diseases in many areas. Rhizopogon sp. are utilized as raw as well as in cooked forms as vegetable and for the medicinal purpose. The ethnomycological survey related to edibility status of mushrooms was undertaken in the study area, and it was observed that as many as 24 mushroom spp. were preferentially consumed by the native populations of the area and a few species were marketed as source of income. Species of Geopora, Cantharellus, Pleurotus, and Lentinus were found in the local markets, while as Morchella species fetched a handsome income through contractors who used to go door to door in the tribal areas for their purchases. Nine species of mushrooms were used as folklore medicines. During the survey on an average 20 respondents belonging to different age groups from three different sites of the study area were interviewed and information regarding the edibility status, medicinal uses and general information was recorded (Table 2). It was observed that people from Rafiabad, Handwara and Kupwara have a good knowledge of mushroom utilization with reference to food and ethnomedicinal uses as compared to Wagoora and Baramulla. Moreover, it was also observed that people within the age group of 50-80 years had a good knowledge of mushrooms as compared to the youngsters and below 30 years of age, the people had less information or not familiar with regard to mushrooms, their edibility and ethnomedicinal value. 


\section{DISCUSSION}

Wild edible mushrooms have been utilized for food and medicines since thousands of years ago. They are important sources of food for tribal communities who mostly live in the forest and depend on natural resources for their livelihood. It was revealed from this study that out of 100 species of mushrooms collected from the surveyed area, 33 species were used by the local inhabitants and herbalists (Hakims) as a source of ethnomedicines, functional food or purely as food. The ethnomedicinal mushrooms included Ganoderma species, C. cibarius, Flammulina velutipes, B. edulis, Morchella species, and Fomes fomentarius. B. plumbea, L. tigrinus, Rhizopogon species, and P. ostreatus have been used as functional foods whereas Agaricus species, G. sumneriana, N. lepideus, P. Impudicus, and L. deliciosus are widely consumed as food. Morchella species, Cantharellus cibarius, G. sumneriana, Helvella, and Coprinus species are sold in the local markets to earn some income. The documentation of ethnomedicinal value of mushrooms has been carried out for the first time in the study area. Edibility status of most of the mushrooms documented in the surveyed areas was confirmed from the literature and has been found widely consumed in Northern Himalayas, north eastern states of India [22-26]. However, precautions were made by the tribal people to utilize only the easily identifiable mushrooms both for domestic and commercial purposes. The ethnomedicinal value reported in this study has also been found by earlier workers [9-11,27] which have been further substantiated by many workers for their antioxidant value and presence of essential mineral elements and secondary metabolites [4,28-32]. Studies on the antioxidant activity of Pleurotus florida, Calocybe indica, and Volvariella volvacea has revealed that these mushrooms could serve natural rich oxidant foods and thereby enhance immune system against oxidative damage $[33,34]$. Oral herbal dosage form of Agaricus bisporus powder in the form of tablets have been reported to have antidiabetic properties [35] thereby confirms the practice of using mushroom powder by many herbalists as ethnomedicines as reported in this study. Mushroom is being treated as the potential source of new generation of antioxidants [36] such as nutrition and antioxidants of plant products against oxidative stress and for prevention and treatment of a large number of diseases [37]. Therefore, the ethnomedicinal studies of mushrooms to explore their therapeutic potential become important.

It is important to mention here that the herbalists and hakims used some of the species for medicinal purposes either through food supplements or in combination with some other herbal plants or modified forms giving some preliminary treatments. However, much information was not sought about the preliminary treatments given to the mushroom products. Only a few hakims, herbalists and mushroom hunters revealed the complete knowledge they had, while others could not do so without citing the reasons. Any extract of mushrooms to be taken as such is prohibited because of toxic nature of some of the mushrooms as the herbalists give some preliminary treatments to the mushrooms before their use and the authors do not take any responsibility for any untoward for mushroom consumption before their proper identification.

\section{CONCLUSIONS}

It is concluded from the above study that ethnomedicinal knowledge is restricted to the elder people. Therefore, it becomes imperative to document the information on wild edible and medicinal mushrooms to pass on this knowledge to future generations. It is also emphasized that to avoid the ignorance of the edibility and medicinal value local inhabitants need to be trained to collect and conserve this natural wealth on scientific pattern without overexploitation and local inhabitants and the tribal communities should be sensitized about the ethnomedicinal value of mushrooms. Moreover, this study will form the base line for researchers and the mushrooms used by local inhabitants can be further evaluated for medicinal value and bioactive compounds.

\section{Acknowledgment}

Authors are thankful to the Head Department of Botany, University of Kashmir for providing necessary library and laboratory facilities.
The authors also acknowledge the cooperation of mushroom hunters, local people, tribals and herbalists, which they rendered from time to time. The corresponding author acknowledges the support of UGC for providing FIP fellowship.

\section{REFERENCES}

1. Boa E. Wild edible fungi: A global overview of their use and importance to people. Non-Wood Forest Products Series, No. 17. Rome: FAO; 2004.

2. Chang ST, Buswell JA. Mushroom nutriceuticals. World J Microbiol Biotechnol 1996;12(5):473-6.

3. Chang ST, Miles PG. Mushrooms: Cultivation, Nutritional Value, Medicinal Effect, and Environmental Impact. II ${ }^{\text {nd }}$ ed. New York: CRC Press; 2004. p. 451.

4. Wani BA, Bodha RH, Wani AH. Nutrional and medicinal importance of mushrooms. J Med Plants Res 2010;4(24):2598-604.

5. Wasser SP. Medicinal mushroom science: History, current status, future trends, and unsolved problems. Int J Med Mushrooms 2010;12(1):1-16.

6. Lakhanpal TN, Shad O, Rana M. Biology of Indian Morels. New Delhi: I K International Publishing; 2010.

7. Borchers AT, Stern JS, Hackman RM, Keen CL, Gershwin ME. Mushrooms, tumors, and immunity. Proc Soc Exp Biol Med 1999;221:281-93.

8. Sanodiya BS, Thakur GS, Baghel RK, Prasad GB, Bisen PS. Ganoderma lucidum: A potent pharmacological macrofungus. Curr Pharm Biotechnol 2009;10(8):717-42.

9. Hobbs C. Medicinal Mushrooms: An Exploration of Tradition, Healing and Culture. $2^{\text {nd }}$ ed. Santa Cruz, CA, USA: Botanica Press; 1995.

10. Pala SA, Wani AH, Bhat MY. Ethnomycological studies of some wild medicinal and edible mushrooms in the Kashmir Himalayas (India). Int J Med Mushrooms 2013;15(2):211-20.

11. Panda KM, Tayung K. Documentation and ethno medicinal knowledge on wild edible mushrooms among ethnic tribes of Northern Odisha, India. Asian J Pharm Clin Res 2015;8(4):139-43.

12. Vishwakarma MP, Bhatt RP, Gairola S. Some medicinal mushrooms of Garhwal Himalaya, Uttarakhand, India. Int J Med Arom Plants 2011;1(1):33-40.

13. Kumar S, Sharma YS. Diversity of wild mushrooms from Jammu and Kashmir. In: Proceedings of the $7^{\text {th }}$ International Conference on Mushroom Biology and Mushroom Products, October 4-7. Arcachon, France: INRA; 2011. p. 588-77.

14. Halling RE. Recommendations for collecting mushrooms for scientific study. In: Alexiades MN, Sheldon JW, editors. Selected Guidelines for Ethnobotanical Research: A Field Manual. New York, Bronx: Botanical Garden Press; 1996.

15. Kuo M. Making Spore Prints; 2001. Available from: http://www. bluewillopages.com/mushroomexpert/herbarium.html.

16. Kuo M. Agrocybe molesta; 2006. http://www.mushroomexpert.com/ agrocybe_molesta.html.

17. Arora D. Mushrooms Demystified. Berkeley: Ten Speed Press; 1986

18. Kuo M. Mushroom Taxonomy Mushroom Expert. Com.; 2003. Available from: http:/www.mushroomexpert.com/taxonomy.html.

19. Lincoff GH. The Audubon Society Field Guide to North American Mushroom. New York: Alfred A, Knopt; 1981.

20. Atri NS, Saini SS. Collection and study of agarics-an introduction. Indian J Mushrooms 2000;18(1-2):1-5.

21. Atri NS, Kaur A, Kaur H. Wild mushrooms collection and identification. Mushroom Res 2003;14:56-9.

22. Kumar S, Sharma YP. Diversity of wild mushrooms from Jammu and Kashmir. In: Proceedings of the $7^{\text {th }}$ International Conference on Mushroom Biology and Mushroom Products, (ICMBMP7); 2011.

23. Okigbo RN, Nwatu CM. Ethnostudy and usage of edible and medicinal mushrooms in some parts of Anambra state, Nigeria. Nat Resour 2015;6:79-89.

24. Chauhan J, Negi AK, Rajasekaran A, Pala NA. Wild edible macrofungi - A source of supplementary food in Kinnaur district, Himachal Pradesh, India. J Med Plants Stud 2014;2(1):40-4

25. Sagar A, Chauhan A, Sehgal AK. Ethnobotanical study of some wild edible mushrooms of tribal district Kinnaur of Himachal Pradesh. Indian J Mushroom 2005, XXIII:1-8.

26. Yongabi K, Agho M, Carrera MD. Ethnomycological studies on wild mushrooms in Cameroon, Central Africa. Micol Apl Int 2004; 16(2):34-6

27. Kumari B, Atri NS, Upadhya RC. Culinary staus and sociobiology of termitophilous and lepiotoid mushrooms of North West India. World J 
Agric Sci 2015;8(4):415-20

28. Keles A, Koca I, Genccelep H. Antioxidant properties of wild edible mushrooms. J Food Process Technol 2011;2:1-6.

29. Rex DA. Selenium enriched mushrooms as a food supplement for prevention of neurodegenerative diseases. Int Pharm Pharm Sci 2014;6(10):1-2.

30. Tripathy SS, Rajoriya A, Mahapatra A, Nibha G. Biochemical and antioxidant properties of wild edible mushrooms used for food by tribal of Eastern India. Int J Pharm Pharm Sci 2016;8(4):194-9.

31. Falandysz J. Selenium in edible mushrooms. J Environ Sci Health C Environ Carcinog Ecotoxicol Rev 2008;26(3):256-99.

32. Wani AH, Boda RH, Nissa T, Peer LA. Potential antioxidant activity of some mushrooms growing in Kashmir Valley. Mycopath 2010;8(2):71-5.
33. Kalava SV, Menon SG. In vitro free radical scavenging activity of aqueous extract from the mycelia of Volvariella volvacea (Bulliard EX fries) singer. Int J Curr Pharm Res 2012;4(3):94-100.

34. Prabu M, Kumuthakalavalli R. Antioxidant activity of oyster mushroom (Pleurotus florida [Mont.] Singer) and milky mushroom (Calocybe indica $\mathrm{P}$ and C). Int J Curr Pharm Res 2016;8(3):48-51.

35. Srivastava S, Panda P, Vishwakarma DK, Verma NK, Nayak J. Formulation and evaluation of herbal tablets containing Agaricus bisporus powder. Int J Adv Pharm 2017;6(2):63-9.

36. Khatua S, Paul S, Acharya K. Mushroom as the potential source of new generation of antioxidant: A review research. J Pharm Technol 2013;6(5):497-505.

37. Kale MA, Bindu SM, Khadkikar P. Role of antioxidants and nutrition in oxidative stress: A review. Int J Appl Pharm 2015;7(1):1-4. 